\title{
HUBUNGAN PENGETAHUAN TENTANG SEKSUAL SELAMA KEHAMILAN TRIMESTER DENGAN PERILAKU SEKSUAL IBU HAMIL TRIMESTER III DI PUSKESMAS SUNGAI DURIAN KABUPATEN KUBU RAYA TAHUN 2017
}

\section{Yovan Hendrik ${ }^{1}$, Chahyani Erlita ${ }^{2}$}

\author{
Akademi Kebidanan Panca Bhakti Pontianak \\ Email korespondensi: akbidpbpontianak@gmail.com
}

\begin{abstract}
Abstrak
Trimester ketiga merupakan periode ketika wanita mulai banyak mengalami rasa tidak nyaman selama kehamilan. Hubungan seksual tidak dilarang selama tidak ada masalah dalam kehamilan, kecuali pada ibu hamil resiko tinggi. Studi pendahuluan yang peneliti lakukan terhadap 10 orang ibu hamil trimester III, 8 orang mengatakan tidak tahu bahwa hubungan seksual boleh dilakukan pada saat hamil dan 8 orang tidak tau posisi yang benar melakukan hubungan seksual pada kehamilan trimester III. Tujuan dari penelitian ini adalah untuk mengetahui hubungan pengetahuan tentang seksual selama kehamilan trimester dengan perilaku seksual ibu hamil trimester iii di puskesmas sungai durian kabupaten kubu raya tahun 2017. Penelitian ini menggunakan jenis penelitian deskriptif korelasional dengan pendekatan cross sectional. Populasi penelitian yaitu seluruh ibu hamil trimester III perioder Januari hingga Februari 2017 sebanyak 474 orang. Peneliti menggunakan 10\% jumlah populasi sebanyak 47 orang sebagai sampel. Pengumpulan data menggunakan kuesioner Kemudian diolah dan dianalisis menggunakan analisis univariat serta analisis bivariat menggunakan uji chi square. Hasil penelitian menunjukkan responden memiliki pengetahuan baik yaitu sebanyak 32 responden $(68,09 \%)$. Sebanyak 31 responden $(65,96 \%)$ melakukan hubungan seksual selama kehamilan trimester III. Hasil perhitungan secara statistik dengan rumus Chis square didapatkan hitung adalah 4,693 sedangkan angka pada tabel Chi square dengan df 1 dengan kepercayaan 95\% adalah tabel yaitu 3,841. Dengan demikian hitung $(4,693)>$ tabel $(3,841)$ berarti ada hubungan yang signifikan antara pengetahuan tentang seksual selama kehamilan trimester III dengan perilaku seksual selama kehamilan trimester III. Oleh karena itu perlu adanya upaya peningkatan pengetahuan ibu hamil trimester III melalui penyuluhan, konseling, pendidikan kesehatan, pembagian leafleat dan poster tentang hubungan seksual selama kehamilan trimester III.
\end{abstract}

Kata Kunci: Pengetahuan, Perilaku Seksual, Hamil Trimester III

\section{Pendahuluan}

Kehamilan adalah fertilisasi atau

penyatuan dari spermatozoa dan ovum

kemudian dilanjutkan dengan nidasi atau implantasi. Bila dihitung dari saat fertilisasi hingga lahirnya bayi, kehamilan normal akan berlangsung dalam waktu 40 minggu atau 9 bulan menurut kalender internasional. Kehamilan terbagi menjadi 3 trimester, dimana trimester kesatu berlangsung dalam 12 minggu, trimester kedua 15 minggu (minggu ke- 13 hingga ke- 27), dan trimester ketiga 13 minggu

\footnotetext{
${ }^{1}$ Dosen Akademi Kebidanan Panca Bhakti Pontianak

${ }^{2}$ Dosen Akademi Kebidanan Panca Bhakti Pontianak
}

(minggu ke- 28 hingga ke-40) (Prawirohardjo, 2013).

Kehamilan trimester III, yaitu dimulai dari bulan ke tujuh dimana bagian-bagian tubuh janin semakin sempurna seperti tangan, kaki beserta kukunya, bulu mata sudah mulai tumbuh dan dapat membuka dan menutup. Meskipun ginjal dan paru-paru sudah terbentuk namun oksigen masih disuplai melalui aliran darah pada tali pusat. Pada bulan kedelapan pertumbuhan janin berkembang pesat, dimana ukuran janin pada usia ini mencapai berat 
sekitar $1,5 \mathrm{~kg}$ dan panjang sekitar $45-50 \mathrm{~cm}$. bulan ke delapan di usia menjelang kelahiran ini perkembangan pada janin lebih bersifat penyempurnaan. Jaringan lemak terus bertambah dan berfungsi sebagai penghangat tubuh bayi, menjelang kelahiran posisi janin akan turun menempati rongga punggung dengan posisi kepala di bawah (Kusumawati, 2008).

Trimester ketiga merupakan periode ketika wanita mulai banyak mengalami rasa tidak nyaman selama kehamilan. Misalnya, sangat sukar untuk menemukan posisi yang nyaman waktu tidur, lebih sering bermimpi tentang kehidupan. Mimpi tentang kehilangan bayi atau melahirkan bayi mati merupakan olahan psikologis bawah sadar dari akibat yang tidak diharapkan dan merupakan jalan untuk membawa rasa takut ini kepermukaan (Zaman, 2014).

Pada ibu hamil ada beberapa hal yang boleh bahkan harus dilakukan ibu hamil antara lain minum air yang cukup yaitu minimal 8 gelas sehari, menungging karena dapat membantu janin menemukan posisi yang tepat agar tidak sungsang. Ibu hamil juga diharuskan banyak berjalan. Dan ada beberapa hal yang hendaknya tidak boleh dilakukan oleh ibu hamil antara lain merokok atau perokok pasif tidak minum minuman beralkohol karena dapat menimbulkan kecacatan fisik maupun psikis bagi janin dalam kandungan, ibu hamil juga tidak boleh melakukan diet karena dapat menyebabkan kurang vitamin (Purbo, 2008).

Hubungan seksual tidak dilarang selama tidak ada masalah dalam kehamilan, kecuali pada ibu hamil resiko tinggi seperti pernah mengalami abortus spontan, partus prematurus, perdarahan antepartum, dan ketuban pecah dini, sangat di anjurkan untuk tidak melakukan hubungan seksual (Prawirohardjo, 2011). Seksual dalam kehamilan adalah aspek kesehatan yang penting tetapi jarang dibicarakan dengan baik. Pada umumnya wanita hamil malu untuk memulai pembicaraan mengenai seksual dan bidan pun merasa takut mencampuri privacy orang lain sehingga ragu untuk mendiskusikannya.

Ada beberapa kepercayaan, budaya yang tabu untuk melakukan hubungan seksual selama hamil hal ini menyebabkan kegelisahan pada beberapa pasangan, oleh karena itu perlu didiskusikan secara terbuka (Indrayani, 2011). Ibu hamil biasanya memiliki perubahan kebutuhan akan perhatian dan keintiman dalam hubungan dengan pasangannya. Dari sisi emosional, ibu hamil lebih sensitif, dan keintiman sudah bisa mereka rasakan lewat sentuhan atau sekedar bicara berdua dengan pasangan di tempat tidur sambil berpegangan tangan. Sungguh pun demikian, hubungan seksual selama masa kehamilan sama sekali tidak dilarang (Misky, 2012).

Pola hubungan seksual ibu hamil trimester III di pengaruhi oleh hormone progesterone, dimana wanita akan merasa pusing, lemas dan gairah seksual menurun, pada fase ini wanita akan malas melakukan hubungan seksual. Melakukan hubungan seksual selama kehamilan memang tidak masalah, tetapi hendaknya disesuaikan dengan kondisi wanita tersebut agar terasa nyaman di kedua pihak pasangan. Dimana melakukan hubungan seksual akan lebih baik di lakukan 
pada trimester III karena kondisi fisik dan mental ibu hamil mendukung, tentunya dengan posisi seksual yang tepat (Charissa, 2011).

Berdasarkan hasil penelitian Anugrah L Putra yang berjudul Hubungan Pengetahuan dengan Perilaku Seksual Pada Ibu Hamil Trimester III di Puskesmas Sekaran Semarang Tahun 2013, hasilnya dari 85 responden, yang memiliki kategori tingkat pengetahuan kurang $36,5 \%$ tentang hubungan seksual pada ibu hamil, tingkat pengetahuan sedang 9,4\% tentang hubungan seksual pada ibu hamil, tingkat pengetahuan baik $54,1 \%$ tentang hubungan seksual pada ibu hamil. Hal tersebut dapat disebabkan oleh beberapa faktor, seperti faktor internal dan eksternal.

Berdasarkan hasil penelitian dari 85 responden, yang memiliki kategori perilaku kurang sebanyak 31,8\% dalam perilaku seksual, perilaku sedang sebanyak 49,4\% dalam perilaku seksual, perilaku baik sebanyak $18.8 \%$ dalam perilaku seksual. Hal ini dikarenakan karena kecendrungan dan pola kebiasaan dari diri responden itu sendiri. Hasil penelitian menemukan bahwa ada hubungan yang signifikan antara pengetahuan dengan perilaku seksual pada ibu hamil trimester III di Puskesmas Sekaran Semarang dengan hasil uji hitung $(34,645)$ lebih besar dari pada tabel $(5,99)$ dan pvalue $(0,000)<0,05$ maka ditolak atau di terima.

Berdasarkan hasil penelitian Fitriana Ikhtiarinawati Fajrin yang berjudul Hubungan Tingkat Pengetahuan Ibu Hamil Tentang Seks Selama Kehamilan dengan Melakukan Hubungan Seks Selama Masa Kehamilan di Polindes Desa Jabung Kecamatan Laren
Kabupaten Lamongan Tahun 2015. Hasilnya Pengetahuan Ibu Hamil Tentang Seks Selama Kehamilan bahwa dari 25 ibu hamil masih banyak yang berpengetahuan kurang yaitu sebanyak 15 responden (60\%) dengan pendidikan kurang dan yang mengalami saat melakukan hubungan seksual selama kehamilan sebanyak 12 responden (80\%). Sedangkan 3 responden (20\%) yang tidak melakukan hubungan seksual. Sedangkan 10 responden yang berpengetahuan baik (40\%), 9 responden tidak melakukan hubungan seksual selama kehamilan dan 1 responden (10\%) yang melakukan hubungan seksual Selama masa kehamilan.

Berdasarkan perhitungan dengan menggunakan uji kofisien phi di dapatkan uji hitung $(17,779) \mathrm{p}$ value $(0,001)<0,05$ maka ditolak atau di terima berarti ada hubungan pengetahuan ibu hamil tentang seks selama masa kehamilan dengan kecemasan ibu hamil melakukan hubungan seksual selama masa kehamilan. Berdasarkan hasil penelitian Nindia Permatasari yang berjudul Hubungan Persepsi Seksual dengan Perilaku Seksual Masa Kehamilan Pada Ibu Hamil Trimester I di Puskesmas Banguntapan III Bantul Yogyakarta Tahun 2015 hasilnya yaitu dari 30 responden sebanyak 24 responden (80\%) dengan hasil persepsi seksual pasangan cukup.

Persepsi pasangan baik sebanyak 4 orang $(13,3 \%)$, persepsi seksual pasangan kurang yaitu 2 responden $(6,7 \%)$. Kemudian sebanyak 10 responden $(33,3 \%)$, perilaku baik dalam melakukan hubungan seksual selama kehamilan trimester I. 20 responden $(66,7 \%)$, berperilaku cukup baik dalam melakukan hubungan seksual 
selama kehamilan trimester I, sedangkan tidak ada responden (0\%), perilaku kurang baik dalam melakukan hubungan seksual selama kehamilan trimester I. Terdapat hubungan antara persepsi seksual dengan perilaku seksual pada ibu hamil trimester I dan suami di Puskesmas Banguntapan III Bantul Yogyakarta, yang di tunjukan dengan hasil uji Kendall Tau di peroleh angka signifikan p 0,043 $<0,05$ Ho ditolak, Ha diterima (Permatasari, 2015).

Berdasarkan data yang diperoleh dari Kementrian Kesehatan Republik Indonesia jumlah ibu hamil di Indonesia tahun 2014 adalah 5.290.235 orang. Dan data yang di peroleh dari Dinas Kesehatan Provinsi Kalimantan Barat jumlah ibu hamil di Kalimantan Barat Tahun 2014 berjumlah 104.762 orang. Kemudian jumlah ibu hamil di Kabupaten Kubu Raya Tahun 2014 berjumlah 11.212 jiwa (Dinkes RI, 2015). Berdasarkan data yang diperoleh di Puskesmas Sungai Durian jumlah ibu hamil pada bulan Januari sampai Desember Tahun 2016 adalah 4.873 orang. Dengan jumlah K1 2.466 orang dan K4 2.407 orang (Puskesmas Sungai Durian, 7 Maret 2017).

Studi pendahuluan yang peneliti lakukan terhadap 10 orang ibu hamil trimester III, 8 orang mengatakan tidak tahu bahwa hubungan seksual boleh dilakukan pada saat hamil dan 8 orang tidak tahu posisi yang benar melakukan hubungan seksual pada kehamilan trimester III, dan selama ini mereka cenderung takut untuk melakukan hubungan seksual bahkan tidak melakukan hubungan seksual sama sekali selama kehamilan trimester III, ada juga beberapa ibu hamil merasa cemas jika melakukan hubungan seksual dengan alasan takut bayinya akan lahir tidak cukup bulan dan terjadi perdarahan.

\section{Metode}

Penelitian ini menggunakan jenis penelitian deskriptif korelasional dengan pendekatan cross sectional. Penelitian dilaksanakan pada bulan Februari hingga Juni 2017 di Puskesmas Sungai Durian Kabupaten Kubu Raya. Populasi penelitian yaitu seluruh ibu hamil trimester III perioder Januari hingga Februari 2017 sebanyak 474 orang. Peneliti menggunakan $10 \%$ jumlah populasi sebanyak 47 orang sebagai sampel. Pengumpulan data menggunakan kuesioner, kemudian diolah dan dianalisis menggunakan analisis univariat serta analisis bivariat menggunakan uji chi square.

\section{Hasil dan Pembahasan}

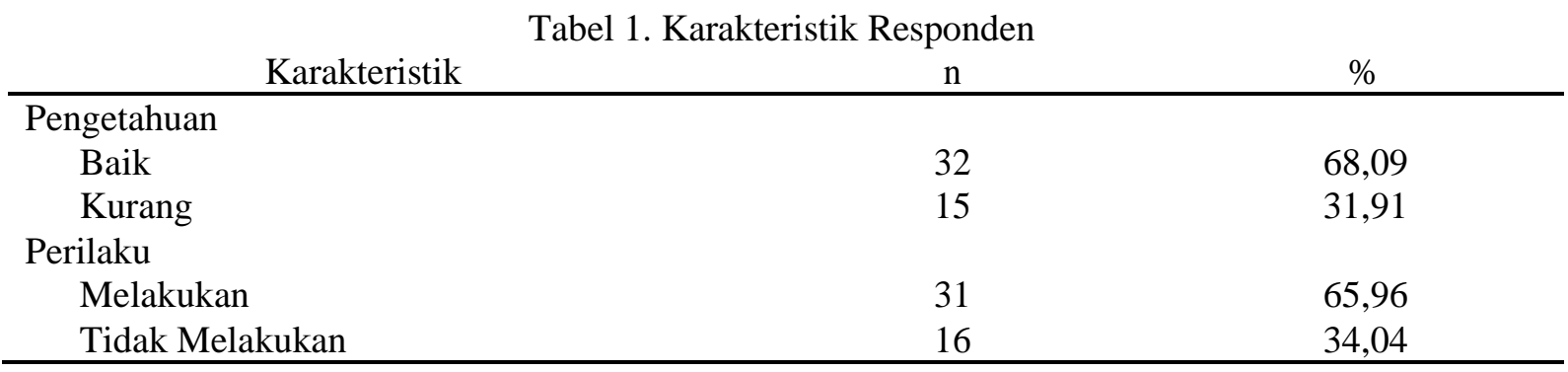


Berdasarkan tabel 1 menjelaskan bahwa sebagian besar dari responden memiliki pengetahuan baik yaitu sebanyak 32 responden (68,09\%). Berdasarkan tabel 1 menjelaskan bahwa sebagian besar dari responden yaitu sebanyak 31 responden $(65,96 \%)$ melakukan hubungan seksual selama kehamilan trimester III.

Tabel 2. Analisis Bivariat

\begin{tabular}{|c|c|c|c|c|c|c|c|}
\hline \multirow{4}{*}{ Variabel } & \multicolumn{4}{|c|}{ Sikap } & \multirow{2}{*}{\multicolumn{2}{|c|}{ Total }} & \multirow{4}{*}{$X^{2}$} \\
\hline & & dak & \multicolumn{2}{|c|}{ Mendukung } & & & \\
\hline & \multicolumn{2}{|c|}{ Mendukung } & \multirow[b]{2}{*}{$\mathrm{N}$} & \multirow[b]{2}{*}{$\%$} & \multirow[b]{2}{*}{$\mathrm{N}$} & \multirow[b]{2}{*}{$\%$} & \\
\hline & $\mathrm{N}$ & $\%$ & & & & & \\
\hline \multicolumn{8}{|l|}{ Pengetahuan } \\
\hline Baik & 30 & 93,75 & 2 & 6,25 & 32 & 100 & 4,693 \\
\hline Kurang & 1 & 6,67 & 14 & 93,33 & 15 & 100 & \\
\hline
\end{tabular}

Berdasarkan tabel 2 menjelaskan bahwa sebagian besar dari responden memiliki pengetahuan baik yaitu sebanyak 32 responden $(69,09 \%)$ dan sebagian kecil dari responden yaitu sebanyak 15 responden $(31,91 \%)$ berpengetahuan kurang. Adapun faktor yang berkaitan dengan pengetahuan responden diantaranya adalah faktor pengetahuan, karena sebagian besar responden yang berpengetahuan baik berpendidikan SMA dan perguruan tinggi, sedangkan responden yang berpengetahuan kurang lebih banyak berpendidikan SMP dan SD. Hal ini sependapat dengan teori Wahit (2007), yang menyatakan bahwa pengetahuan seseorang dapat dipengaruhi oleh faktor pendidikan, pekerjaan, umur, minat, pengalaman, kebudayaan, dan informasi.

Demikian juga hasil penelitian ini didukung oleh hasil penelitian Fajarita Senjayani yang berjudul Tingkat Pengetahuan Ibu Hamil Tentang Hubungan Seksual Selama Kehamilan Di BPM Sri Winarti Purbayan Baki Sujoharjo Tahun 2015, hasilnya dari 40 responden sebagian besar dari responden yaitu 33 orang responden $(82,5 \%)$ berpengetahuan baik dan sangat sedikit dari responden yaitu sebanyak 7 orang responden $(17,5)$ berpengetahuan kurang.

Hal ini sesuai dengan pendapat Notoatmodjo (2010), yang mengatakan bahwa pengetahuan merupakan hasil pengindraan manusia, atau hasil tahu seseorang terhadap objek melalui indra yang di milikinya (mata, hidung, telinga, dan sebagainya). Berdasarkan tabel 2 menjelaskan bahwa sebagian besar dari responden yaitu 31 orang responden $(65,96 \%)$ melakukan hubungan seksual selama kehamilan trimester III dan sebagian kecil dari responden yaitu sebanyak 16 orang responden $(34,04 \%)$ tidak melakukan hubungan seksual selama kehamilan trimester III.

Dari hasil penelitian yang dilakukan didapatkan hasil lebih banyak responden yang melakukan hubungan seksual selama kehamilan trimester III dibandingkan responden yang tidak melakukan hubungan seksual selama kehamilan trimester III. Adapun alasan responden tidak melakukan hubungan seksual selama kehamilan trimester III dikarenakan sebagian responden percaya akan mitos yang beredar di masyarakat, 
yaitu berhubungan seksual selama kehamilan trimester III dapat menyebabkan bayi lahir premature dan perdarahan. Hal ini sesuai dengan pendapat Lawrence Green (1980), bahwa ada beberapa faktor yang mempengaruhi perilaku seseorang yaitu faktor predisposisi, faktor pendukung, dan faktor pendorong (Hikmawati,2011).

Hasil penelitian ini sesuai dengan hasil penelitian Fitriana yang berjudul Tingkat Pengetahuan Ibu Hamil Tentang Seks Selama Kehamilan dengan Melakukan Hubungan Seks Selama Masa kehamilan, dari 25 responden yang tidak melakukan hubungan seksual selama kehamilan sebagian dari responden yaitu sebanyak 13 orang (52\%) dan yang melakukan hubungan seksual yaitu sebanyak 12 orang $(48 \%)$.

Penemuan ini juga diperkuat dengan pendapat Hikmawati (2011), yang mengatakan perilaku adalah semua kegiatan atau aktifitas manusia, baik yang dapat diamati secara langsung, maupun yang tidak dapat diamati oleh pihak luar. Hal ini sependapat dengan Fitriana (2007), yang menyatakan seharusnya ibu hamil baik melakukan hubungan seksual selama kehamilan trimester III dikarenakan dapat menguatkan ikatan fisik dan emosional antara ibu dan pasangan.

Oleh karena itu penulis dapat menyimpulkan pada hasil penelitian ini terdapat faktor lain yang mempengaruhi perilaku responden yang tidak melakukan hubungan seksual selama kehamilan trimester III, namun yang paling dominan adalah pengetahuan. Berdasarkan tabel 2 diketahui bahwa dari 47 responden yang diteliti yaitu 32 responden yang berpengetahuan baik, diantaranya hampir seluruh dari responden yaitu sebanyak 30 responden $(93,75 \%)$ melakukan hubungan seksual selama kehamilan trimester III dan sangat sedikit dari responden yaitu sebanyak 2 responden $(6,25 \%)$ tidak melakukan hubungan seksual selama kehamilan trimester III. Sedangkan dari 15 responden yang berpengetahuan kurang, diantaranya sangat sedikit dari responden yaitu sebanyak 1 orang responden $(6,67 \%)$ melakukan hubungan seksual selama kehamilan trimester III, dan hampir seluruh dari responden yaitu sebanyak 14 orang responden $(93,33 \%)$ tidak melakukan hubungan seksual selama kehamilan trimester III.

Hasil perhitungan secara statistik dengan rumus Chis square didapatkan hitung adalah 4,693 sedangkan angka pada tabel Chi square dengan df 1 dengan kepercayaan 95\% adalah tabel yaitu 3,841. Dengan demikian hitung $(4,693)>$ tabel $(3,841)$ berarti ada hubungan yang signifikan antara pengetahuan tentang seksual selama kehamilan trimester III dengan perilaku seksual selama kehamilan trimester III.

Hal ini sesuai dengan teori Sylvia (1998), yang menyatakan bahwa semakin tinggi tingkat pengetahuan dan pemahaman mengenai hubungan seksual selama kehamilan maka dapat meningkatkan perilaku seksual sehingga frekuensi seksual dalam batas normal (Aini, 2013). Didukung pula oleh pendapat Winkjosatro (2000), yang menyatakan bahwa faktor yang mempengaruhi frekuensi seksual dalam kehamilan adalah lingkungan dan pengetahuan, karena semakin rendah pengetahuan seseorang maka akan timbul 
perilaku seseorang yang sangat berpengaruh terhadap frekuensi berhubungan seksual (Aini, 2013)

Diperkuat dengan hasil penelitian Anugrah L Putra yang berjudul Hubungan Pengetahuan dengan Perilaku Seksual Pada Ibu Hamil Trimester III di Puskesmas Sekaran Semarang Tahun 2013. Hasil penelitian menemukan bahwa ada hubungan yang signifikan antara pengetahuan dengan perilaku seksual pada ibu hamil trimester III dengan hasil uji hitung $(34,645)$ lebih besar dari pada tabel $(5,99)$ dan pvalue $(0,000)>0,05$ maka ditolak atau di terima.

Juga hasil penelitian Fitriana Ikhtiarinawati Fajrin yang berjudul Hubungan Tingkat Pengetahuan Ibu Hamil Tentang Seks Selama Kehamilan dengan Melakukan Hubungan Seks Selama Masa kehamilan di Polindes Desa Jabung Kecamatan Laren Kabupaten Lamongan Tahun 2015, Berdasarkan perhitungan dengan menggunakan uji kofisien phi di dapatkan uji hitung $(17,779)$ $\mathrm{p}$ value $(0,001)>0,05$ maka ditolak atau di terima berarti ada hubungan pengetahuan ibu hamil tentang seks selama masa kehamilan dengan kecemasan ibu hamil melakukan hubungan seksual selama masa kehamilan.

\section{Kesimpulan}

Berdasarkan hasil penelitian yang telah dilakukan, maka dapat disimpulkan bahwa ada hubungan yang signifikan antara pengetahuan tentang seksual selama kehamilan trimester III dengan perilaku seksual ibu hamil trimester III. Oleh karena itu perlu adanya upaya peningkatan pengetahuan ibu hamil trimester III melalui penyuluhan, konseling, pendidikan kesehatan, pembagian leafleat dan poster tentang hubungan seksual selama kehamilan trimester III.

\section{Daftar Pustaka}

Aini, H. 2013. Hubungan pengetahuan dengan kecemasan suami dengan frekuensi seksual. http://Harfa-Aini-skripsi.pdf. Diakses 13 maret 2017, 16:47 WIB

Alfianika, Ninit .2016. Buku Ajar Metode Penelitian Pengajaran Bahasa Indonesia. Der Publis: Yogyakarta.

Arif, Nurhaeni. 2008. Panduan Lengkap Kehamilan dan Persalinan Sehat. Dianloka: Yogyakarta

Arikunto, Suharsimi. 2010. Prosedur Penelitian. Rienka Cipta: Jakarta

Fajrin, F.I. 2015. Hubungan Tingkat Pengetahuan Ibu Hamil Tentang Seks Selama Kehamilan Dengan Melakukan Hubungan Seks Selama Masa Kehamilan. http://journal.unisla.ac.id/ pdf/19812016/a.\%20Bu\%Fitri.pdf, di akses, 18 Februari 2017, 15. 55 WIB

Fitriana, Ana. 2007. Panduan Lengkap Kesehatan Wanita. Gala Ilmu Semesta: Yogyakarta

Hartono, Andri. 2014. Catatan Ringkasan Maternal dan Neonatal. Bina Aksara: Tanggerang Selatan

Hastono, S.P. 2010. Statistik Kesehatan. Raja Grafindo Persada: Jakarta Utara

Hidayat, A.A. 2014. Metode Penelitian Kebidanan dan Teknik Analisa Data.Selemba Medika: Jakarta

Hikmawati, Isna. 2011. Promosi Kesehatan. Nuha Medika: Yogyakarta
Indrayani. 2011. Buku
Ajar Asuhan
Kebidanan. CV. Trans Info Media:
Jakarta Timur 
Kusumawati, 2008. Panduan Lengkap Kehamilan dan Persalinan. Tugu Publisher: Yogyakarta

Margareta, Shinta. 2013. 40 Minggu Pertama Yang Penuh Keajaiban Dalam Hidupku. Pustaka Cerdas: Yogyakarta

Marmi. 2011. Asuhan Kebidanan Pada Masa Antenatal. Pustaka Pelajar: Yogyakarta

Misky, Dudy. 2012. Panduan Kesehatan Kehamilan. Arya Pustaka: Yogyakarta

Notoatmodjo, Sukijo.2007. Promosi Kesehatan dan Ilmu Perilaku. Rineka Cipta: Jakarta 2010. Metodologi Penelitian Kesehatan. Rineka Cipta: Jakarta

Permatasari, Ninda. 2015. Hubungan Persepsi Seksual Dengan Perilaku Seksual Masa Kehamilan Pada Ibu Hamil Trimester I Di Puskesmas Banguntapan III Bantul Yogyakarta.http://opac.unisayogya.ac.id /111/1/Naskahpublikasi.pdf

Prawirohardjo, Sarwono. 2011. Ilmu Kandungan. Bina Pustaka. Sarwono Prawirohardjo: Jakarta

Putra, A.L. 2013. Hubungan Pengetahuan Dengan Perilaku Seksual Ibu Hamil TrimesterIII.http://jurma.unimus.ac.i d/index.php/perawat/article/download/1 74/174, diakses: 18 Februari 2017, 15.45 WIB

Purbo, P.R. 2008. Indahnya Menjadi Ibu. Media Ilmu: Yogyakarta

Senjayani, S. 2015. Tingkat Pengetahuan Ibu Hamil Tentang Hubungan Seksual Selama Kehamilan.01-gdl-fajaritase977-1-ktifaja-a.pdf, dikses: 28 Februari 2017, 17:45 WIB

Setiawan, Arif. 2011. Metodologi Penelitian Kebidanan. Nuha Medika: Yogyakarta

Syafrudin, dkk. 2009. Promosi Kesehatan Untuk Maahasiswa Kebidanan. CV. Trans Info Media: Jakarta
2011. Untaian Materi

Penyuluhan KIA. CV. Trans Info Media: Jakarta

Wahit, dkk. 2007. Promosi Kesehatan. Graha Ilmu: Yogyakarta

Zaman, Chairil. 2014. Asuhan Kebidanan Kehamilan Fisiologis dan Patologis. Bina Rupa Aksara: Tanggerang 